\title{
Umarzanie należności z tytułu składek na ubezpieczenia społeczne w świetle orzecznictwa sądów administracyjnych
}

\author{
Remission of Social Security Contributions in the \\ Light of the Jurisprudence of Administrative Courts
}

Streszczenie. Przedmiotem opracowania jest analiza linii orzeczniczych sądów administracyjnych dotyczących umarzania należności z tytułu składek na ubezpieczenie społeczne. Autorzy dokonali przeglądu orzecznictwa sądowego w tym zakresie oraz podjęli próbę ustalenia rozbieżnych linii interpretacyjnych, a także ich oceny. Ponieważ składki na ubezpieczenia społeczne stanowią jedną z danin publicznych, analizę instytucji umorzenia przeprowadzono w szerszym kontekście, tj. porównano zasad umarzania składek na ubezpieczenia społeczne oraz pozostałych danin publicznych. Analiza regulacji prawnych dotyczących instytucji umorzenia danin publicznych pozwoliła stwierdzić, że nie ma jednolitego modelu tego postępowania wspólnego dla wszystkich danin.

Słowa kluczowe: składki na ubezpieczenia społeczne; umorzenie; ulgi w zapłacie; daniny publiczne. 


\begin{abstract}
This article aims to analyze the line in jurisdiction of administrative courts concerning the remission of receivables from social security contributions. The authors reviewed judicial decisions in this area and have attempted to determine the divergent lines of interpretation. Because social security contributions are one of the institutions of public levies analysis was carried out remission in a broader context - compared the rules of remission social security contributions and other public charges. In the author's opinion analysis of legal regulation of remission public levies led to the conclusion that there is no single model of conduct common to all imposts.
\end{abstract}

Keywords: contributions to social insurance; debt relief in payment; public levies.

\title{
1. Wstęp
}

Zagadnieniem wymagającym szczegółowej analizy w ramach badań nad problemem ułatwień w opłacaniu składek na ubezpieczenie społeczne jest interpretacja przepisów regulujących umarzanie należności z tytułu tych składek w orzecznictwie sądów administracyjnych. 1 lipca 2014 r. upłynęło 10 lat od daty objęcia przez sądy administracyjne kontroli nad legalnością rozstrzygnięć organów w sprawach umarzania należności z tytułu składek na ubezpieczenia społeczne, co uzasadnia dokonanie przeglądu orzecznictwa sądowego $\mathrm{w}$ tym zakresie oraz podjęcie próby ustalenia ewentualnych linii interpretacyjnych, a także ich oceny. Ponieważ składki na ubezpieczenia społeczne stanowią jedną z danin publicznych, zasadna wydaje się także analiza instytucji umorzenia w szerszym kontekście, tj. porównania zasad umarzania składek na ubezpieczenia społeczne oraz pozostałych danin publicznych.

Z uwagi na ograniczone ramy niniejszego opracowania analizując orzecznictwo, ograniczono się do regulacji systemowych pomijając problem umarzania należności na podstawie ustaw szczegółowych oraz umarzania należności z tytułu składek ubezpieczeniowych rolników. 


\section{Charakter prawny składek na ubezpieczenia społeczne}

Obowiązujący od 1999 r. system zabezpieczenia społecznego opiera się obecnie na czterech różnych rodzajach zabezpieczeń: emerytalnym, rentowym, chorobowym oraz wypadkowym ${ }^{1}$. Ubezpieczenia te przysługują osobom ubezpieczonym w przypadku powstania okoliczności kwalifikujących je do jednego ze wskazanych ryzyk. Osobami ubezpieczonymi są obligatoryjnie pracownicy w rozumieniu przepisów kodeksu pracy, którym przysługuje pełne prawo ubezpieczenia ${ }^{2}$, oraz w myśl art. 8 ust. 2a u.s.u.s. także osoby wykonujące pracę na podstawie umowy agencyjnej, umowy zlecenia lub innej umowy o świadczenie usług, do której zgodnie z kodeksem cywilnym stosuje się przepisy dotyczące zlecenia lub umowy o dzieło, jeżeli umowę taką zawarto z pracodawcą, z którym pozostaje się w stosunku pracy lub w ramach takiej umowy wykonuje się pracę na jego rzecz. Po stronie ubezpieczonych spoczywa obowiązek uiszczania obowiązkowych składek, z których finansowane są i od których mogą zależeć niektóre świadczenia. W doktrynie przedmiotu określa się tę powinność jako zasadę wzajemności ubezpieczeń społecznych ${ }^{3}$. Składki te wchodzą w skład jednego z przychodów Funduszu Ubezpieczeń Społecznych. W doktrynie podnosi się, że cele i metody tworzenia FUS zakładają, że składka na ubezpieczenie społeczne jest podstawowym źródłem przychodów funduszu i powinna odzwierciedlać wysokość przyszłego świadcze-

1 Należy zaznaczyć, że ustawa z dnia 13 października 1998 r. o systemie ubezpieczeń społecznych (tekst jedn. Dz.U. z 2013 r., poz. 1442 ze zm., dalej: u.s.u.s.) nie reguluje warunków nabywania prawa do świadczeń z poszczególnych ubezpieczeń społecznych. Prawo do świadczeń z ubezpieczeń emerytalnego i rentowych regulowane jest przepisami ustawy z dnia 17 grudnia 1998 r. o emeryturach i rentach z Funduszu Ubezpieczeń Społecznych (tekst jedn.: Dz.U. z 2013 r., poz. 1440). Ustawa z dnia 25 czerwca 1999 r. o świadczeniach pieniężnych z ubezpieczenia społecznego w razie choroby i macierzyństwa (tekst jedn.: Dz.U. z 2014 r., poz. 159) określa warunki nabywania prawa do świadczeń z ubezpieczenia chorobowego, zaś ustawa z dnia 30 października 2002 r. o ubezpieczeniu społecznym z tytułu wypadków przy pracy i chorób zawodowych (tekst jedn.: Dz.U. z 2009 r. Nr 167, poz. 1322 ze zm.) warunki nabywania prawa do świadczeń z ubezpieczenia wypadkowego.

Szerzej: L. Florek, Prawo pracy, Warszawa 2013, s. 339.

Tamże. 
nia ${ }^{4}$. Składki na ubezpieczenie społeczne są zróżnicowane ze względu na tytuł ubezpieczenia, z tym że składka na ubezpieczenie chorobowe, rentowe i emerytalne jest jednakowa dla wszystkich i wyrażona w formie stopy procentowej. W przypadku składki na ubezpieczenie wypadkowe procedura wygląda inaczej, gdyż jej wysokość będzie uzależniona od poziomu zagrożeń zawodowych i ich skutków, dlatego została zróżnicowana dla poszczególnych płatników składek ${ }^{5}$.

Obowiązujący system ubezpieczeń społecznych charakteryzuje przede wszystkim zasada równego traktowania wszystkich ubezpieczonych. Na temat równego traktowania ubezpieczonych wypowiedział się Sąd Najwyższy, podkreślając, że w tym przypadku równe traktowanie nie oznacza ,jednakowości” stosunków ubezpieczenia społecznego wszystkich ubezpieczonych i każdego z nich. Zdaniem Sądu Najwyższego zasady nabywania prawa do świadczeń przez ubezpieczonych będących pracownikami mogą być ukształtowane inaczej niż ubezpieczonych z innych tytułów, w tym z tytułu zatrudnienia na podstawie umowy o pracę nakładczą ${ }^{6}$ Oznacza to, że zasada ta będzie miała wyraźne zastosowanie na poszczególnych etapach procedowania $\mathrm{w}$ zakresie podlegania ubezpieczeniom społecznym. Zgodnie $\mathrm{z}$ art. 2a u.s.u.s. nie można różnicować sytuacji prawnej ubezpieczonych z uwagi na ich płeć, rasę, pochodzenie etniczne, narodowość, stan cywilny lub stan rodzinny; nie można również wywieść zakazu wprowadzenia zróżnicowanych systemów ubezpieczenia społecznego dla pracowników i dla osób prowadzących działalność gospodarczą .

4 Z. Ofiarski, Prawno-finansowa specyfika podsektora ubezpieczeń społecznych, [w:] E. Ruśkowski (red.), System prawa finansowego. Prawo finansowe sektora finansów publicznych, Tom II, Warszawa 2010, s. 330.

5 Szerzej na temat składki i zasad jej naliczania - tamże, s. 330-333.

6 Por. postanowienie Sądu Najwyższego z 8 lutego 2006 r., III UZP 3/05, „Orzecznictwo Sądu Najwyższego Zbiór Urzędowy Izba Pracy, Ubezpieczeń Społecznych i Spraw Publicznych” 2007, nr 5-6, poz. 84.

7 Wyrok SN z 22 stycznia 2002 r., II UKN 58/01, „Orzecznictwo Sądu Najwyższego Zbiór Urzędowy Izba Pracy, Ubezpieczeń Społecznych i Spraw Publicznych” 2003, nr 21, poz. 523 oraz wyrok SN z 28 stycznia 2010 r., II UK 199/09, LEX nr 583811. 


\section{Regulacje prawne dotyczące umarzania należności z tytułu składek na ubezpieczenia społeczne}

Zgodnie z art. 28 ust. 1 u.s.u.s. należności z tytułu składek mogą być umarzane w całości lub w części przez Zakład Ubezpieczeń Społecznych. Na podstawie ust. 2 wskazanego przepisu należności z tytułu składek mogą być umarzane tylko w przypadku ich całkowitej nieściągalności. Z kolei w myśl art. 28 ust. 3a i 3b u.s.u.s. należności z tytułu składek na ubezpieczenia społeczne ubezpieczonych będących równocześnie płatnikami składek na te ubezpieczenia mogą być w uzasadnionych przypadkach umarzane pomimo braku ich całkowitej nieściągalności. Jednocześnie minister właściwy do spraw zabezpieczenia społecznego został delegowany, by w drodze rozporządzenia ustalić szczegółowe zasady umarzania w tej sytuacji, z uwzględnieniem przesłanek uzasadniających umorzenie, biorąc pod uwagę ważny interes osoby zobowiązanej do opłacenia należności z tytułu składek oraz stan finansów ubezpieczeń społecznych. Obowiązujące zasady umarzania zostały ustalone w Rozporządzeniu Ministra Gospodarki, Pracy i Polityki Społecznej z dnia 31 lipca 2003 r. w sprawie szczegółowych zasad umarzania należności z tytułu składek na ubezpieczenia społeczne ${ }^{8}$. Zgodnie z $§ 3$ ust. 1 r.z.u. ZUS może umorzyć należności z tytułu składek, jeżeli zobowiązany wykaże, że ze względu na stan majątkowy i sytuację rodzinną nie jest w stanie opłacić tych należności, ponieważ pociągnęłoby to zbyt ciężkie skutki dla zobowiązanego i jego rodziny, w szczególności w przypadku, gdy opłacenie należności z tytułu składek pozbawiłoby zobowiązanego i jego rodzinę możliwości zaspokojenia niezbędnych potrzeb życiowych; w sytuacji poniesienia strat materialnych w wyniku klęski żywiołowej lub innego nadzwyczajnego zdarzenia powodujących, że opłacenie należności z tytułu składek mogłoby pozbawić zobowiązanego możliwości dalszego prowadzenia działalności; a także z powodu przewlekłej choroby zobowiązanego lub konieczności sprawowania opieki nad przewlekle chorym członkiem rodziny, po-

$8 \quad$ Dz.U. Nr 141, poz. 1365 (dalej: r.z.u.). 
zbawiającej zobowiązanego możliwości uzyskiwania dochodu umożliwiającego opłacenie należności. Warto zwrócić uwagę na to, że w treści r.z.u. zawarte zostało sformułowanie, które odnosi się do obowiązku wnioskodawcy w zakresie wykazania przesłanek umorzenia (,jeżeli zobowiązany wykaże”).

Na podstawie art. 30 u.s.u.s., regulacji dotyczących umorzenia nie stosuje się do składek finansowanych przez ubezpieczonych niebędących płatnikami składek ${ }^{9}$. Zwrócić należy uwagę, że ponieważ przepis ten odnosi się wyłącznie do „składek finansowanych przez ubezpieczonych”, nie wyłącza on możliwości umorzenia odsetek za zwłokę, opłaty dodatkowej oraz kosztów upomnienia w postępowaniu egzekucyjnym ${ }^{10}$, a także tej części składki pracowników, która jest finansowana przez pracodawcę. W związku z treścią art. 123 u.s.u.s. postępowanie w przedmiocie umorzenia należności z tytułu składek na ubezpieczenia społeczne toczy się na podstawie przepisów ustawy z 14 czerwca 1960 r. Kodeks postępowania administracyjnego ${ }^{11}$.

Niezależnie od wskazanych powyżej regulacji systemowych szczegółowe zasady umarzania poszczególnych składek zawarte zostały w ustawach odrębnych (np. regulacje takie zawiera ustawa z dnia 24 kwietnia 2009 r. o zmianie ustawy o systemie ubezpieczeń społecznych oraz ustawy - Prawo bankowe ${ }^{12}$ ).

9 Na temat ratio legis tego rozwiązania zob. J. Wantoch-Rekowski, Umarzanie należności z tytułu składek na ubezpieczenia społeczne, „Praca i Zabezpieczenie Społeczne” 2004, nr 3, s. 34.

10 W doktrynie podnosi się, że koszty postępowania egzekucyjnego inne niż koszty upomnienia co do zasady nie podlegają umorzeniu na podstawie przepisów u.s.u.s., lecz przepisów regulujących postępowanie egzekucyjne - tak J. Wanotch-Rekowski (red.), Ustawa o systemie ubezpieczeń społecznych. Komentarz, Toruń-Warszawa 2007, s. 219.

11 Tekst jedn. Dz.U. z 2013 r., poz. 267 ze zm. (dalej: k.p.a.). Rozwiązanie to jest spójne z treścią art. $180 \S 1$ k.p.a., który przewiduje, że w sprawach z zakresu ubezpieczeń społecznych stosuje się przepisy tego kodeksu, chyba że przepisy dotyczące ubezpieczeń ustalają odmienne zasady postępowania.

Dz.U. Nr 71, poz. 609. 


\section{Zasady umarzania należności z tytułu danin publicznych}

Analiza regulacji dotyczących umarzania należności z tytułu składek na ubezpieczenie społeczne oraz orzeczeń sądów administracyjnych, w których odnoszono się do specyfiki tych składek ${ }^{13}$, skłania w pierwszej kolejności do ogólniejszej refleksji dotyczącej zasad umarzania danin publicznych. W szczególności powstaje wątpliwość dotycząca tego, czy w zakresie umarzania tych należności ustawodawca posługuje się jakimś jednolitym modelem postępowania. Jednocześnie nawet jeżeli model taki nie występuje, to zasadne wydaje się ustalenie ewentualnych wspólnych cech normatywnych, charakteryzujących postępowania w sprawie umorzenia danin publicznych. Daniny publiczne należy przy tym rozumieć, zgodnie z art. 5 ust. 2 pkt 1 ustawy z 27 sierpnia 2009 r. o finansach publicznych $^{14}$ jako podatki, składki, opłaty, wpłaty z zysku przedsiębiorstw państwowych i jednoosobowych spółek Skarbu Państwa, a także inne świadczenia pieniężne, których obowiązek ponoszenia na rzecz SP, j.s.t., państwowych funduszy celowych oraz innych jednostek sektora finansów publicznych wynika z odrębnych ustaw ${ }^{15}$. Obowiązujące przepisy przewidują kilka grup regulacji odnoszących się do umarzania poszczególnych danin publicznych.

Oprócz wspomnianych należności z tytułu składek na ubezpieczenie społeczne, obowiązujące przepisy przewidują przede wszystkim odrębne zasady dotyczące zobowiązań podatkowych. Zgodnie z treścią art. 67a § 1 pkt 3 ustawy z 29 sierpnia 1997 r. Ordynacja podatkowa ${ }^{16}$ organ podatkowy na wniosek podatnika, z zastrzeżeniem art. 67b, w przypadkach uzasadnionych ważnym interesem podatnika lub interesem publicznym może umorzyć w całości lub w części zaległości podatkowe, odsetki za

13 Np. wyrok Wojewódzkiego Sądu Administracyjnego z 15 maja 2008 r., V SA/Wa 397/08, Centralna Baza Orzeczeń Sądów Administracyjnych (CBOSA).

14 Tekst jedn. Dz.U. z 2013 r., poz. 885 ze zm. (dalej: u.f.p.).

15 Szerzej na temat pojęcia i rodzajów danin publicznych - W. Wójtowicz, Daniny publiczne [w:] System prawa finansowego. Prawo daninowe Tom III, pod red. L. Etela, Warszawa 2010, s. 15-22.

16 Tekst jedn. Dz.U. 2012 r., poz. 749 ze zm. (dalej: o.p.). 
zwłokę lub opłatę prolongacyjną. Z uwagi na treść art. 2 § 1 i 2 o.p. zakres stosowania przepisów o.p. odnośnie do ulg w zapłacie podatku jest szeroki, ponieważ stosowane są także do opłat, do których ustalania lub określania uprawione są organy podatkowe, oraz opłat i niepodatkowych należności budżetu państwa, do których ustalania lub określania uprawnione są inne organy, jeżeli przepisy odrębne nie stanowią inaczej.

Kolejna grupa regulacji dotyczy stosowania ulg w zapłacie niepodatkowych należności budżetowych. W myśl art. 64 w zw. z art. 67, art. 60 oraz art. 55 u.f.p., na wniosek zobowiązanego środki publiczne stanowiące niepodatkowe należności budżetowe o charakterze publicznoprawnym (zakres tego pojęcia jest przy tym w części odmienny od zakresu „daniny publicznej”) mogą być umarzane w całości lub części na zasadach przewidzianych w u.f.p. i odpowiednio - dziale III o.p.

Obowiązują również szczegółowe zróżnicowane regulacje odnoszące się do poszczególnych danin, w tym np. art. 6q ustawy z dnia 13 września 1996 r. o utrzymaniu czystości i porządku w gminach, który w zakresie opłaty za gospodarowanie odpadami w pełnym zakresie, czyli również odnośnie do ulg w zapłacie, odsyła do regulacji o.p. Wskazać należy także na szczegółowe unormowania, które w zakresie niektórych danin odsyłają do działu III o.p., wyłączają jednak możliwość stosowania przepisów regulujących ulgi w zapłacie (np. art. 281 ust. 2 i 3 ustawy z dnia 27 kwietnia $2001 \mathrm{r}$. Prawo ochrony środowiska ${ }^{17} \mathrm{w}$ zakresie opłat związanych $\mathrm{z}$ korzystaniem ze środowiska).

Odwołując się do powołanych zasad, należy uznać, że umarzanie danin publicznych nie stanowi instytucji w pełni jednorodnej. Elementem wspólnym dla umarzania wszystkich danin publicznych jest natomiast to, że w toku postępowania organy stosują uznanie administracyjne ${ }^{18}$. Ponieważ stosowanie instytucji umorzenia oparte jest na uznaniu administracyjnym, w doktrynie uznaje się, że ma ono charakter dwustopniowy. W pierwszej kolejności organ rozstrzygający sprawę powinien ustalić, czy

Tekst jedn. Dz.U. z 2013 r., poz. 1232 ze zm.

18 Szerzej na temat uznania administracyjnego: zob. Z. Leoński, Zarys prawa administracyjnego, Warszawa 2004, s. 289-291; J. Orłowski, Uznanie administracyjne w prawie podatkowym, Gdańsk 2005, s. 15-26. 
w sprawie zaistniały przesłanki warunkujące możliwość zastosowania umorzenia, a następnie podjąć decyzję, czy na podstawie przysługującego mu uznania administracyjnego stosuje tę ulgę. Organ działa w ramach uznania administracyjnego, decydując o wyborze konsekwencji prawnych (co najmniej dwóch) zaistnienia sytuacji związanej z hipotezą normy prawnej $^{19}$. Z uwagi na uznanie administracyjne organ może więc nie uwzględnić wniosku, pomimo że zachodzą przesłanki (organ nie ma zatem obowiązku zastosowania ulgi). Poza uznaniem pozostaje natomiast ocena wystąpienia w konkretnej sytuacji przesłanek zastosowania ulg. Przesłanki warunkujące możliwość umorzenia zawarte są w treści regulacji prawnych i są to zwykle zwroty niedookreślone, których treść należy każdorazowo łączyć z konkretną sprawą.

Elementem wspólnym dla umarzania wszystkich danin publicznych jest również to, że jeżeli wniosek o umorzenie składa podmiot prowadzący działalność gospodarczą, udzielenie ulgi następuje z uwzględnieniem reguł udzielania pomocy publicznej.

Podsumowując, elementami wspólnymi w zakresie umarzania danin publicznych jest stosowanie w tym zakresie uznania, ograniczenia możliwości umarzania należności przedsiębiorców z uwagi na regulacje pomocy publicznej, a także to, że postępowanie toczy się w oparciu o przepisy procedury podatkowej lub administracyjnej, czego konsekwencją jest kontrola rozstrzygnięć organów przez wojewódzkie sądy administracyjne.

W oparciu o stwierdzone cechy wspólne należy stwierdzić, że obowiązujące przepisy nie zawierają w pełni jednolitych regulacji odnoszących się do umarzania danin publicznych. Rozwiązanie takie jest w pełni uzasadnione tym, że daniny publiczne pełnią różne cele i tym samym różne będą zasady zarówno ich wymiaru, jak i umarzania ${ }^{20}$. W związku z tym wspólny schemat przebiegu postępowania w tych sprawach (toczącego się w oparciu o regulacje k.p.a. lub o.p.) oparty jest na uznaniu

19 Tak w zakresie stosowania uznania w zakresie umorzenia zaległości podatkowych B. Brzeziński, M. Kalinowski, A. Olesińska, Ordynacja podatkowa. Komentarz. Zobowiqzania podatkowe, Toruń 1999, s. 239.

20 Por. J. Wanotch-Rekowski, Umarzenie należności..., s. 37. 
administracyjnym i w tym zakresie można uznać, że jest to wspólna cecha normatywna tego rodzaju postępowań.

Z uwagi na stwierdzone powyżej różnice w tym miejscu powstaje wątpliwość dotycząca kryteriów wyboru przez ustawodawcę zasad umarzania w odniesieniu do poszczególnych danin publicznych, w szczególności w zakresie wprowadzania ograniczeń, przykładowo poprzez uszczegóławianie przesłanek warunkujących umorzenie. W orzecznictwie w zakresie umarzania należności z tytułu składek na ubezpieczenie społeczne wskazuje się, że zobowiązania z tytułu tych składek są w tym kontekście „uprzywilejowane”, ponieważ podlegają zaspokojeniu przed innymi należnościami, są objęte długim terminem przedawnienia oraz z racji specyficznych celów przeznaczenia dysponowanie nimi wymaga zachowania „szczególnej staranności i ostrożności” (zob. wyrok WSA z 15 maja 2008 r.).

W oparciu o powyższą tezę pozornie tylko sformułować można jednak ogólny wniosek, że ustawodawca, uwzględniając znaczenie daniny w kontekście konieczności zagwarantowania niezakłóconych wpływów z jej tytułu, dopuszczając możliwość jej umarzanie, decyduje się na ograniczenie organów administracyjnych w tym zakresie. Przykład składek na ubezpieczenie społeczne, w wypadku których ZUS jest bardziej ograniczony w stosowaniu uznania w porównaniu - przykładowo - z organami podatkowymi, nie jest bowiem wymierny dla oceny regulacji dotyczących pozostałych danin. W wypadku niektórych danin publicznych, co do których ustawodawca w ogóle wykluczył możliwość ich umorzenia (np. opłaty za korzystanie ze środowiska), trudno bowiem postawić tezę, iż z punktu widzenia potrzeb budżetowych traktowane są w sposób bardziej „uprzywilejowany” w porównaniu z innymi daninami, np. podatkami. Zachowanie równowagi budżetowej w wypadku budżetu zarówno państwa, jak i j.s.t. zależy bowiem w większym stopniu od dochodów podatkowych niż wpływów z niektórych opłat, w tym stanowiących dochód budżetu województwa opłat za korzystanie ze środowiska. Z kolei to w wypadku zaległości podatkowych organy mają największą możliwość stosowania instytucji umorzenia, z uwagi na szeroko sformułowane przesłanki umorzenia. Dodatkowo zwrócić należy uwagę, że stosują one prze- 
pisy procedury podatkowej, która przewiduje mniejszą ochronę praw strony niż np. regulacje procedury administracyjnej. Pogląd o tym, że ustawodawca, decydując się na reżim w zakresie umorzenia każdej daniny publicznej, uwzględnia np. jej znaczenie w kontekście wpływu na stan finansów publicznych, można podać w wątpliwość.

Poszukując jednolitych kryteriów decydujących o ograniczeniu możliwości umarzania niektórych danin publicznych, trzeba zauważyć, że nie wydaje się, by ustawodawca stosował regułę, zgodnie z którą ograniczona jest możliwość umarzania tych danin, które mają charakter sankcyjny ${ }^{21}$. Takiemu założeniu ustawodawcy przeczy np. niebudząca obecnie wątpliwości możliwość umorzenia opłaty dodatkowej wymierzanej na podstawie art. 24 ust. 1a u.s.u.s. w związku z nieopłaceniem składek lub opłaceniem ich w zaniżonej wysokości.

Analiza obowiązujących regulacji nie wskazuje także na to, że wybór ustawodawcy co do zasad umarzania danin publicznych jest determinowany rodzajem podmiotu (np. z uwzględnieniem statusu przedsiębiorcy lub tego, że jest on jednostką organizacyjną).

Konkludując, kryteria wyboru przez ustawodawcę zasad umarzania w odniesieniu do poszczególnych danin publicznych nie wydają się jednolite oraz trudno jest je ustalić w wypadku części danin. O ile kryteria te są czytelne w wypadku należności z tytułu składek na ubezpieczenie społeczne, to problematyczne jest ich jednoznaczne ustalenie w wypadku pozostałych danin publicznych. Nie można jednocześnie wskazać jednolitego i uzasadnionego kryterium, które decyduje o tym, że ustawodawca ogranicza możliwość umorzenia poszczególnych danin publicznych oraz nie stosuje takich ograniczeń w stosunku do innych.

21 Zob. przykładowo w bezpodstawnym stanowisku prezentowanym przez Ministerstwo Finansów uznano, że z uwagi na sankcyjny charakter opodatkowania dochodów nieujawnionych 75-procentową stawką podatkową, wykluczone było „podejmowanie działań mających na celu umorzenie zaległości podatkowych powstałych w związku z nieuregulowaniem nałożonej sankcji” (zob. pismo Ministerstwa Finansów z 3 lipca 2001 r., nr GN 8/KK/150/2001, „Serwis Podatkowy” 2002, nr 3, s. 26). 


\section{Problemy orzecznicze dotyczące umarzania należności z tytułu składek na ubezpieczenia społeczne}

\section{1. „Ciężar dowodu” w postępowaniu dowodowym}

Analiza orzeczeń sądów administracyjnych regulujących umarzanie należności z tytułu składek prowadzi do wniosku, że najistotniejsze rozbieżności wywołuje stosowanie przepisów proceduralnych. Na tym tle największe spory wywołuje kwestia istnienia „ciężaru dowodowego” w toczącym się postępowaniu o umorzenie należności z tytułu składek. W tym zakresie ukształtowały się bowiem odrębne linie orzecznicze.

Zgodnie z pierwszą grupą orzeczeń ciężar dowodu okoliczności podniesionych przez wnioskującego o umorzenie spoczywa na zobowiązanym, co wynika wprost z treści § 3 ust. 1 r.z.u., który stanowi, że „zobowiązany wykaże” istnienie przesłanek warunkujących umorzenie. Sądy stwierdzają zatem, że to zobowiązany ma wykazać ZUS okoliczności, z których wynika, że mimo ściągalności składek, należy je jednak umorzyćc $^{22}$. W orzecznictwie podkreśla się również, że wprawdzie postępowanie o umorzenie należności jest procesem administracyjnym, rządzącym się swoistymi, charakterystycznymi regułami i podlegającym konkretnym reżimom prawnym, to jednak należy mieć na uwadze podstawową zasadę polskiego systemu prawa, że ciężar udowodnienia faktu spoczywa na osobie, która z faktu tego wywodzi skutki prawne. Dostrzegając, że w procedurze administracyjnej nie można wprawdzie stosować art. 6 Kodeksu cywilnego sąd uznał, że jednak doktryna i orzecznictwo wypracowały stanowisko, zgodnie z którym w sytuacji, gdy strona z jakiegoś faktu, zdarzenia wynosi skutki prawne, musi to udowodnićéc

Z kolei zgodnie z drugą linią orzeczniczą ciężar dowodu obciąża nie wnioskodawcę, lecz wyłącznie organ administracyjny. Sądy wskazują

22 Wyrok Naczelnego Sądu Administracyjnego z 16 października 2012 r., II GSK 1401/11, CBOSA.

23 Wyrok WSA z 22 listopada 2012 r., I SA/Gl 318/12 oraz wyrok WSA z 15 maja 2008 r., V SA/Wa 459/08, CBOSA. 
przy tym, że na podstawie art. 7 k.p.a. w toku postępowania organy administracji publicznej stoją na straży praworządności i podejmują wszelkie kroki niezbędne do dokładnego wyjaśnienia stanu faktycznego oraz do załatwienia sprawy, mając na względzie interes społeczny i słuszny interes obywateli. Zgodnie z art. $77 \S 1$ k.p.a. organ administracji publicznej jest bowiem obowiązany w sposób wyczerpujący zebrać i rozpatrzyć cały materiał dowodowy ${ }^{24}$. W sytuacji zatem, gdy strona przedstawi niepełny materiał dowodowy, to organ ma obowiązek z własnej inicjatywy podjąć działania w celu jego uzupełnienia ${ }^{25}$. Można spotkać się wręcz ze stanowiskiem, że to nie strona ma udowodnić, że ulga może być zastosowana, lecz organ powinien logicznie wykazać, dlaczego ulgi takiej nie zastosował ${ }^{26}$.

Oceniając powołane linie orzecznicze, należy stwierdzić, że postępowanie w sprawie umarzania należności z tytuł składek, podobnie jak każde postępowanie administracyjne, ma charakter wyłącznie gabinetowy, natomiast $\mathrm{w}$ toku postępowania dowodowego organ zobowiązany jest do przestrzegania m.in. zasady prawdy obiektywnej, zasady czynnego udziału strony w postępowaniu oraz zasady swobodnej oceny dowodów, co ma gwarantować ochronę strony. Z tych powodów należy odrzucić pogląd dotyczący przerzucenia ciężaru dowodowego na zobowiązanego niezależnie od tego, czy rozwiązanie takie wynika z przepisów r.z.u. ${ }^{27}$ Jako błędny należy bowiem uznać pogląd, że przepis zawarty w tym rozporządzeniu zmienia charakter postępowania administracyjnego, którego zasady są expressis verbis zawarte $\mathrm{w}$ treści ustawy ${ }^{28}$. Istota postępowania administracyjnego wyklucza natomiast obowiązek dowodzenia przez wnioskodawcę jakichkolwiek okoliczności faktycznych, jakkolwiek strona postę-

\footnotetext{
Wyrok WSA z 11 lutego 2009 r., I SA/Bd 791/08, CBOSA.

Wyrok WSA z 17 kwiecień 2009 r., III SA/Wr 604/08, CBOSA.

Wyrok WSA z 19 stycznia 2011 r., I SA/Kr 1959/10, CBOSA.

Podać należy w wątpliwość w ogóle zasadność posługiwanie się terminem „ciężar dowodowy” w postępowaniu w sprawie toczącej się na podstawie przepisów k.p.a. odnośnie takich zastrzeżeń w postępowaniu podatkowym zob. B. Brzeziński, M. Masternak, O tak zwanym ciężarze dowodu w postępowaniu podatkowym, „Przegląd Podatkowy” 2004, nr 5, s. 56 i n.

28 W doktrynie kwestionuje się zarówno fakt ustawowej delegacji do ustalenia przez ministra zasad umarzenia należności, jak i sposób, w jaki sformułowano upoważnienie (tak J. Wantoch-Rekowski, Umarzanie należności..., s. 36).
} 
powania, nie przedstawiając dowodów, musi liczyć się z ewentualnym negatywnym skutkiem. Należy w tym miejscu przytoczyć tezę, iż zasada oficjalności nie zwalnia strony postępowania od współudziału w realizacji obowiązku współuczestniczenia w postępowaniu, zwłaszcza w sytuacji, gdy nieudowodnienie określonej czynności faktycznej może prowadzić do rezultatów niekorzystnych dla strony ${ }^{29}$. Interesujące spostrzeżenie znalazło się także w wyroku WSA z 14 stycznia $2011 \mathrm{r}^{30}$, w którym stwierdzono, że de lega ferenda istnieje konieczność wprowadzenia zasady, że to konkretny podmiot musi udowodnić fakty, z których wywodzi skutki prawne. Sąd zaznaczył przy tym, że de lege lata na gruncie prawa administracyjnego jednak nie można mówić o ciężarze dowodu obciążającym stronę postępowania, która nie ma równej pozycji z organem administracyjnym.

Problemem rozstrzyganym w orzecznictwie sądowym, który również wiąże się z „ciężarem dowodowym”, jest wymagany zakres badania przez ZUS przesłanek umorzenia. Jeżeli bowiem uznać, że w postępowaniu o umorzenie składek obowiązek dowodzenia obciąża wyłącznie zobowiązanego, to w tej sytuacji organ nie ma obowiązku badać przesłanek innych niż zawarte we wniosku o umorzenie. Jednocześnie zapadły wyroki sądowe, w których uznaje się, że organ powinien rozważyć szczegółowo wszystkie przesłanki ustawowe wymienione taksatywnie - kwestię istnienia bądź nieistnienia w konkretnej sprawie okoliczności uzasadniających skorzystanie z omawianej instytucji oraz ewentualnie okoliczności uzasadniające zakres ich stosowania ${ }^{31}$.

\subsection{Oznaczenie organu wydającego decyzję w sprawie $\mathrm{z}$ wniosku o ponowne rozpoznanie sprawy}

W orzecznictwie wątpliwości budzi prawidłowe oznaczenie organu wydającego decyzję po rozpatrzeniu wniosku o ponowne rozpoznania sprawy. W treści art. 83 ust. 4 u.s.u.s. wskazano bowiem, że od decyzji ZUS stro-

\footnotetext{
Wyrok WSA z 3 grudnia 2013 r., V SA/Wa 1754/13, CBOSA.

I SA/Kr 1396/10, CBOSA.

Wyrok WSA z 12 sierpnia 2008 r., V SA/Wa 1105/08 oraz wyrok WSA z 15 maja 2009 r., I SA/Po 174/09, CBOSA.
} 
nie przysługuje prawo do wniesienia wniosku do Prezesa Zakładu o ponowne rozpatrzenie sprawy. Do 2009 r. sądy administracyjne uznawały słusznie, że wadliwe jest wskazanie Prezesa Zakładu w nagłówku decyzji, skoro nie jest on organem podejmującym tę decyzję. Zgodnie z art. 107 § 1 k.p.a. decyzja powinna bowiem zawierać oznaczenie organu, który ją wydał. Jednocześnie w wyrokach sądów powszechnie przyjmowano, że taki błąd w oznaczeniu organu nie ma istotnego wpływu na wynik sprawy, o ile z treści decyzji wynika, że podjęta zostały przez właściwy organ, tj. ZUS $^{32}$. W 2009 r. wydana została jednak grupa wyroków, w których wychodząc z założenia, że organem wydającym decyzję w trybie art. 83 ust. 4-6 u.s.u.s. jest ZUS, a nie Prezes Zakładu, decyzja w której nagłówku oznaczono Prezesa ZUS wydana została przez organ niewłaściwy, co skutkuje stwierdzeniem jej nieważności ${ }^{33}$.

Jako rozstrzygający prawidłowo powyższą kwestię należy uznać wyrok NSA z 22 listopada 2012 r. ${ }^{34}$, w którym uznano, że sformułowanie zawarte w art. 83 ust. 4 u.s.u.s., dotyczące adresata wniosku o ponowne rozpatrzenie sprawy, jakim jest Prezes Zakładu, ma charakter przepisu technicznego, regulującego czysto organizacyjną kwestię na czyje ręce kierowany jest taki wniosek, nie zaś przepisu normującego właściwość tego organu do rozpoznania tego środka procesowego, gdyż takim organem jest ZUS. Uchybienie sądu (tym samym również uchybienie w tym zakresie organów administracyjnych) polegające na oznaczeniu prezesa ZUS jako strony zostało uznane jako niemające wpływu na wynik sprawy. Sąd uznał, że w sprawie występuje jako organ ZUS, a nie Prezes Zakładu, który nie występuje w imieniu własnym, ale w imieniu i na rzecz ZUS.

\subsection{Obowiązek ustalania istnienia należności}

Istotnym problemem poruszanym w wyrokach sądów administracyjnych był obowiązek ustalania przez ZUS istnienia należności, o których umo-

\footnotetext{
Wyrok WSA z 17 grudnia 2008 r., II SA/Go 713/08, CBOSA.

Tak m.in. wyrok WSA z 21 maja 2009 r., III SA/Po 246/09, CBOSA.

II GSK 1689/11, CBOSA.
} 
rzenie występuje zobowiązany. Jako poprawną należy uznać w tym zakresie tezę, zgodnie z którą umorzyć można tylko te należności, które istnieją, podczas gdy przedawnione zobowiązania z tytułu składek wygasają ${ }^{35}$. Jednocześnie w zakresie obowiązku ustalenia istnienia należności w toku postępowania pojawił się pogląd, który należy zakwestionować, zgodnie z którym zagadnienie faktycznego istnienia należności wykracza poza ocenę zasadności odmowy umorzenia odsetek za zwłokę od nieopłaconych w terminie składek. Sądy uznały, że nie mają podstaw prawnych do oceny, czy wysokość zadłużenia wobec ZUS została przez ten organ prawidłowo ustalona oraz czy w ogóle istnieje. Sąd stwierdził, że mając wątpliwości co do określonej przez organ kwoty należności z tytułu nieopłaconych składek wraz z odsetkami, zobowiązany powinien wystąpić ze stosownym wnioskiem do organu w celu otrzymania decyzji wymiarowej w trybie określonym w art. 83 ust. 1 pkt 3 u.s.u.s. Sąd zauważył również, iż złożenie wniosku o umorzenie należności z tytułu składek winno nastąpić dopiero wówczas, gdy strona zgadza się z kwotą zadłużenia, a jedynie z różnych względów nie jest w stanie jej pokryćc ${ }^{36}$.

\subsection{Wyłączenie pracownika ZUS od udziału w postępowaniu}

W myśl art. $24 \S 1$ pkt 5 k.p.a. pracownik organu administracji publicznej podlega wyłączeniu od udziału w postępowaniu w sprawie, w której brał udział w niższej instancji w wydaniu zaskarżonej decyzji. W związku z interpretacją powyższego przepisu powstał problem, jak w wypadku spraw o umorzenie należności z tytułu składek na ubezpieczenie społeczne rozumieć zwrot „,brał udział w niższej instancji w wydaniu zaskarżonej decyzji”. Zgodnie z wyrokiem WSA z 22 grudnia 2008 r. ${ }^{37}$ osoby jedynie parafujące zaskarżoną decyzję nie mogą być uznać za pracowników biorących udział w postępowaniu w rozumieniu art. 24 § 1 pkt 5 k.p.a. „Para-

35 Wyrok WSA z 12 maja 2008 r., V SA/Wa 426/08 oraz wyrok WSA z 23 listopada 2011 r., I SA/Bd 736/11, CBOSA.

36 Wyrok WSA z 26 maja 2008 r., V SA/Wa 878/08 oraz wyrok WSA z 6 sierpnia 2008 r., V SA/Wa 1021/08, CBOSA.

37 III SA/Gl 1349/08, CBOSA. 
fowanie” decyzji nie oznacza udziału w jej wydaniu, gdyż osoby te nie były osobami upoważnionymi do podpisywania, czyli wydawania decyzji w imieniu Prezesa ZUS. Jednocześnie w wyroku WSA z 23 listopada 2011 r. $^{38}$, którego tezę należy podzielić, stwierdza się, że przez „udział w wydaniu zaskarżonej decyzji” w niższej instancji należy rozumieć nie tylko wydanie (podpisanie) decyzji przez pracownika, lecz także podejmowanie czynności procesowych mających lub mogących mieć wpływ na wynik (rozstrzygnięcie) sprawy.

Zwrócić należy uwagę na linię orzeczniczą dotycząca spraw podatkowych, z której wynika, że decyzja „podpisana” przez więcej niż jedną osobę (w wypadku organu monokratycznego), nawet jeżeli podpisy są skutkiem „parafowania”, rodzi uzasadnione przypuszczenie, że rozstrzygnięcie to zostało podjęte przez nieprzewidziany przepisami prawa organ kolegialny (tak np. wyrok WSA z 29 września 2011 r., I SA/Rz 467/11, CBOSA).

\subsection{Przedmiotowy zakres umorzenia należności z tytułu składek}

Z istotnych problemów materialnoprawnych, które pojawiły się w orzecznictwie sądów administracyjnych, wskazać należy na możliwość umarzania na podstawie art. 28 ust. 3a u.s.u.s. składek, które opłacane są przez pracodawcę będącego płatnikiem w części w jakiej finansuje te składki. W orzecznictwie zarysowały się dwa stanowiska.

Zgodnie z wyrokiem WSA z 10 października 2008 r. ${ }^{39}$ oraz wyrokiem NSA z 8 listopada 2007 r. ${ }^{40}$ ponieważ wnioskodawca jest - w myśl art. 4 pkt 1 u.s.u.s. - ubezpieczonym oraz - w myśl art. 4 pkt 2 ppkt a) i d) u.s.u.s. - płatnikiem składek z dwóch tytułów: jako pracodawca i jako osoba ubezpieczona zobowiązana wyłącznie do opłacenia składek na wła-

\footnotetext{
I SA/Bd 736/11, CBOSA.

V SA/Wa 989/08, CBOSA.

I GSK 244/07, CBOSA. Podobnie przyjął NSA w uzasadnieniu wyroku z 27 maja 2011 r., II GSK 588/10, CBOSA.
} 
sne ubezpieczenie społeczne, należy stwierdzić, iż spełnione są przesłanki $\mathrm{z}$ art. 28 ust. 3a ustawy.

Z kolei w wyroku WSA z 17 listopada 2008 r. $^{41}$ oraz wyrok NSA z 12 marca 2008 r. $^{42}$ potwierdzono prawidłowość wykładni art. 28 ust. 3a u.s.u.s zastosowanej przez ZUS, która wskazuje na brak prawnych możliwości umorzenia zadłużenia zobowiązanego za zatrudnionych pracowników w części finansowanej przez płatnika tych składek pracowniczych. W ocenie sądów należności takie mogą być umarzane jedynie w sytuacji stwierdzenia całkowitej nieściągalności należności, zgodnie z art. 28 ust. 2 u.s.u.s. Argumentem, który ma wspierać to stanowisko, jest również twierdzenie, że z uwagi na to, że przepisy regulujące umorzenie mają charakter wyjątku od reguły, należy je interpretować ściśle, a nie rozszerzająco.

\section{Wnioski końcowe}

Analiza orzeczeń sądów administracyjnych w zakresie umarzania należności z tytułu składek na ubezpieczenie społeczne prowadzi do wniosku, że powstałe problemy orzecznicze nie różnią się od tych, które pojawią się w toku umarzania innych danin publicznych. Z uwagi na specyfikę postępowań opartych na stosowaniu uznania administracyjnego zdecydowana większość wyroków odnosi się przy tym, podobnie jak w wypadku wyroków w sprawach umarzania np. zaległości podatkowych, do kwestii proceduralnych związanych z prawidłowym przebiegiem postępowania przed ZUS, głównie w zakresie gromadzenia oraz oceny materiałów dowodowych.

Oceniając dotychczasowe orzecznictwo sądów administracyjnych, należy stwierdzić, że jedyną kwestią, która z uwagi na rozbieżność w orzecznictwie wymaga rozstrzygnięcia poprzez zmianę przepisu, jest tzw. ciężar dowodu. Zmiana przepisu r.z.u. powinna polegać na wykreśleniu wskazania na wnioskodawcę jako podmiotu, na którym spoczywa ciężar dowodowy, lub zmianie brzmienia przepisu poprzez wskazanie na obowiązek współdziałania zobowiązanego z organem w związku z nega-

41 V SA/Wa 982/08, CBOSA.

42 II GSK 451/07, CBOSA. 
tywnym konsekwencjami w zakresie ustalenia stanu faktycznego. W pozostałym zakresie jakkolwiek orzecznictwo co do wskazanych wyżej kwestii jest w pewnym stopniu rozbieżne (np. prawidłowe oznaczenie organu w decyzji, wyłączenia od załatwienia sprawy pracowników) oraz wyjątkowo odmienne od linii orzeczniczych w sprawach umorzeń zaległości podatkowych (np. brak obowiązku ustalenia w toku postępowania istnienia należności), to skala tych rozbieżności oraz to, że są one charakterystyczne dla orzeczeń sądowych w innych rodzajach spraw, nie pozwala postawić zarzutu znaczącej niespójności orzecznictwa.

Analiza regulacji prawnych dotyczących instytucji umorzenia danin publicznych pozwala z kolei stwierdzić, że nie ma jednolitego modelu tego postępowania wspólnego dla wszystkich danin. Jednocześnie nie wydaje się konieczne, by model taki stworzyć. Analiza możliwych kryteriów decydujących o trybie i warunkach stosowania instytucji umorzenia wskazuje natomiast, że o ile w wypadku większości danin publicznych nie jest możliwe ustalenie istnienia jednego uzasadnionego kryterium, to w wypadku składek na ubezpieczenie społeczne decydował o tym ich charakter.

\section{Bibliografia:}

Brzeziński B., Kalinowski M., Olesińska A., Ordynacja podatkowa. Komentarz. Zobowiq̨zania podatkowe, TNOiK, Toruń 1999.

Brzeziński B., Masternak M., O tak zwanym ciężarze dowodu w postępowaniu podatkowym, „Przegląd Podatkowy” 2004, nr 5, s. 56-60.

Florek L., Prawo pracy, C.H. Beck, Warszawa 2013.

Leoński Z., Zarys prawa administracyjnego, Wydawnictwo Prawnicze LexisNexis, Warszawa 2004.

Ofiarski Z., Prawno-finansowa specyfika podsektora ubezpieczeń społecznych [w:] E. Ruśkowski (red.), System prawa finansowego. Prawo finansowe sektora finansów publicznych, Tom II, Wolters Kluwer, Warszawa 2010.

Orłowski J., Uznanie administracyjne w prawie podatkowym, ODDK, Gdańsk 2005.

Wantoch-Rekowski J., Umarzanie należności z tytułu składek na ubezpieczenia społeczne, „Praca i Zabezpieczenie Społeczne” 2004, nr 3, s. 33-39. 
Maria Bosak, Paweł Majka

Wantoch-Rekowski J. (red.), Ustawa o systemie ubezpieczeń społecznych. Komentarz, TNOiK, Toruń-Warszawa 2007.

Wójtowicz W., Daniny publiczne [w:] L. Etel (red.), System prawa finansowego. Prawo daninowe Tom III, Wolters Kluwer, Warszawa 2010. 